\title{
AS AGÊNCIAS REGULADORAS E O SEU PODER NORMATIVO
}

REGULATORY AGENCIES AND ITS NORMATIVE POWER

LAS AGENCIAS REGULADORAS Y SU PODER NORMATIVO

CRISTINA ALVES DA SILVA BRAGA

UNIVERSIDADE ANHANGUERA - UNIDERP

CAMPO GRANDE - MS

ROCCO ANTONIO RANGEL ROSSO NELSON

INSTITUTO FEDERAL DO RIO GRANDE DO NORTE - IFRN CAMPUS JOÃO CÂMARA

BRASIL

BRASIL

La justicia, la igualdad del mérito, el trato respetuoso del hombre, la igualdad plena del derecho: eso es la revolución. José Martí. 


\begin{tabular}{c}
\hline CRISTINA ALVES DA SILVA BRAGA - ROCCO ANTONIO RANGEL ROSSO NELSON \\
AS AGÊNCIAS REGULADORAS E O SEU PODER NORMATIVO \\
Pags. $113-133$
\end{tabular}

Recibido: 12/10/2015

Aceptado: 17/03/2016

\title{
RESUMO
}

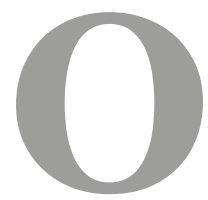

presente trabalho tem como escopo discutir a constitucionalidade do poder normativo das agências reguladoras. Para isso, faz-se necessário traçar essas entidades na linha do tempo de sua evolução, assim como sua natureza jurídica e suas as características específicas para que se possa compreender sua relação e inserção no contexto social, legislativo e jurídico brasileiro. A análise não pode fugir do contexto de uma sociedade que se mostra cada vez mais técnica e complexa, exigindo do Estado atuação compatível com os problemas apresentados pelo grupo social, avaliando se a organização estatal apresenta mecanismos eficientes para atender às demandas sociais e às exigências da Constituição. É assim que se poderá perceber a compatibilidade do poder normativo das agências reguladoras com o que pede e espera a sociedade e com o que exige a Constituição, ou seja, com a concretização de direitos fundamentais, e a realização da vontade constitucional.

Palavras-Chave: agências reguladoras; constitucionalidade; poder normativo.

\begin{abstract}
This work is scoped to argue the constitutionality of the normative power of regulatory agencies. For this, it is necessary to trace these entities on the timeline of their development, as well as their legal nature and its specific characteristics in order to understand their relationship and insertion in the social, legislative and legal context. The analysis cannot escape the context of a society which shows increasingly complex and technical, requiring the State Act compatible with the problems presented by social group, evaluating whether the State Organization presents efficient mechanisms to meet the social demands and the requirements of the Constitution. That's how you may notice the compatibility of normative power of regulatory agencies with what you ask and expect the society and what the Constitution requires, with the realisation of fundamental rights and the realization of the will.
\end{abstract}

Keywords: regulatory agencies; constitutionality; normative power.

\section{RESUMEN}

Este trabajo tiene como objetivo discutir la constitucionalidad del poder normativo de las agencias reguladoras. Para esto, es necesario trazar estas entidades en la línea de tiempo de 
su evolución, así como su condición jurídica y sus características de manera que usted pueda comprender su relación e integración en el jurídico-social, legislativo y brasileña. El análisis no puede escapar el contexto de una sociedad que parece cada vez más técnico y complejo, que requiere la acción del Estado compatibles con los problemas presentados por el grupo social, la evaluación de la organización del Estado cuenta con mecanismos eficaces para satisfacer las demandas sociales y las exigencias de Constitución. Esto es cómo usted puede darse cuenta de la compatibilidad del poder normativo de las agencias reguladoras lo que pide y espera la sociedad y que requiere la Constitución, es decir, la realización de los derechos fundamentales, y la realización de la voluntad constitucional.

Palabras Clave: agencias reguladoras; constitucionalidad; poder normativo.

\section{DAS CONSIDERAÇÕES INICIAIS}

O presente trabalho tem por objetivo trazer ao debate o aspecto da constitucionalidade do poder normativo das agências reguladoras.

Para tanto, faz-se necessário traçar essas entidades na linha do tempo de sua evolução, em breve histórico das mesmas, para que se possa compreender sua relação e inserção no contexto social, legislativo e jurídico brasileiro.

Por consequência, a natureza jurídica e as características específicas dessas autarquias precisam ser aclaradas, o que se buscará fazer como forma de suporte para o entendimento do que elas são em essência e o que representam para a configuração do Estado.

Não há como afastar a análise das agências reguladoras da relação que elas têm com a sociedade e com o Estado, numa aproximação que reflete o Estado como prestador e assegurador de direitos fundamentais e sociais pautados na Constituição da República e a sociedade como beneficiária para quem se dirigem tais direito.

Nessa perspectiva, percebe-se uma sociedade que se mostra cada vez mais técnica e complexa, exigindo do Estado atuação compatível com os problemas apresentados pelo grupo social. É aí que se pode questionar se a organização estatal apresenta mecanismos eficientes para atender às demandas sociais e às exigências da Constituição.

A atuação das agências reguladoras, nesse contexto, se mostra compatível com o que pede e espera a sociedade e com o que exige a Constituição, ou seja, com a efetivação de direitos fundamentais e com a realização da vontade constitucional. A privatização de setores é uma realidade, mas os direitos fundamentais precisam ser protegidos concretizados.

Para isso, é imprescindível observar que a descentralização normativa é imprescindível e que poder normativo das agências tem natureza regulamentar, sendo fruto da delegificação e se direcionando de forma técnica e específica para o setor regulado. Não há exclusão do Poder 
Legislativo, mas uma complementação normativa, dada a impossibilidade de este Poder tratar de forma técnica, específica e célere, matérias que a Constituição quer que sejam assim regulamentadas no compasso da concretização dos direitos fundamentais. É o que se pretende demonstrar.

\section{AS AGÊNCIAS REGULADORAS NO BRASIL}

As agências reguladoras formam, hoje, um conjunto de estruturas originais dentro do aparelho do Estado contemporâneo. Sua criação ocorre em resposta a exigências novas e atestam a insuficiência das estruturas tradicionais para responder aos problemas das sociedades complexas e evolutivas.

Isso porque, o Estado não possui mecanismos suficientes para suprir todas as necessidades da coletividade, de forma a garantir que os direitos fundamentais sejam assegurados na sua integralidade (Amaral, 2008).

No Brasil, um dos pontos de máxima proeminência da reforma administrativa do Estado consistiu no processo de desestatização ocorrido na década de 90, onde foram instituídas medidas para distanciar do poder estatal determinadas atividades, que se achava que seriam desempenhadas mais eficientemente pelo setor privado, bem como, porque o Estado interventor do atual momento não conseguia desempenhar seu papel de forma hábil, fazendose necessário a ocorrência de uma desregulamentação, reduzindo a quantidade de normas limitativas da atividade econômica (Carvalho Filho, 2008).

Logo, no Brasil as agências reguladoras são um instituto bastante recente, surgido a partir de 1996 e fruto do processo de desestatização que se desencadeou a partir de 1990, com a edição da Medida Provisória 155/901, convertida na Lei no 8.031/90, que estabeleceu o chamado "Plano Brasil Novo", no Governo do então presidente Fernando Collor, e posteriormente regulamentado pela Lei n ${ }^{0}$ 9.491/97², que disciplina o Plano Nacional de Desestatização, instituída em Governo posterior, o do presidente Fernando Henrique Cardoso (Amaral, 2008).

A primeira autarquia em regime especial a ter recebido o nome de agência reguladora no Brasil foi a Agência Nacional de Energia Elétrica - ANEEL, constituída pela Lei 9.427, de 1996. Em seguida foram estabelecidas igualmente a Agência Nacional de Telecomunicações ANATEL e a Agência Nacional de Petróleo - ANP, respectivamente pelas Leis 9.472, de 1997, e 9.478 , de 1997.

A criação das agências reguladoras não ocorreu de forma eventual. Insere-se num contexto histórico que ajunta algumas circunstâncias, tais como, crise absoluta e falha do modelo de Estado

${ }^{1}$ BRASIL. Medida Provisória 155/90, de 15 de março de 1990, que cria o programa nacional de desestatização, convertida posteriormente na Lei no. 8.031 de 12 de abril de 1990.

${ }^{2}$ Lei no. 9.491, de 9 de setembro de 1997, que altera procedimentos relativos ao Programa Nacional de Desestatização, revoga a Lei $n^{\circ} 8.031$, de 12 de abril de 1990, e dá outras providências. 
interventor, ora prestador de serviços, o desencadeamento de um processo de desestatização, atribuindo a entes econômicos particulares o direito de prestar serviços públicos, por meio de delegação, que até então eram prestados exclusivamente por empresas estatais, e a necessidade de se conferir segurança e independência aos investimentos estrangeiros (Mendes, 2006).

A Constituição Federal deixou evidente que o setor econômico estaria a cargo da iniciativa privada, conforme se observa no art. 170 da Constituição $0^{3}$, reservando ao Estado o papel de agente normativo e regulador da mesma atividade, segundo o art. 174 da Constituição ${ }^{4}$, a ele só se atribuindo a exploração direta do setor nas situações descritas na forma do art. 173 da Constituição ${ }^{5}$, ou seja, quando necessárias aos imperativos da segurança nacional ou relevante interesse coletivo.

Ressalta-se que as agências reguladoras, sugiram no Brasil, por decisão estritamente política, visando um melhor desempenho do papel do Estado, e da divisão de funções nascidas com o princípio da separação de poderes, como forma de fiscalizar e garantir que as atividades desenvolvidas pela iniciativa privada obedeçam aos ditames estabelecidos pela sociedade no contexto atual.

E a partir da década de 90, começaram a surgir às agências reguladoras inspiradas no modelo norte-americano. Isso porque, diante da ineficiência do intervencionismo do Estado no Governo do então presidente Fernando Henrique Cardoso, houve um fortalecimento da política liberalizante da economia.

Buscou-se diminuir a participação do Estado e um aumento nas atividades desenvolvidas pelos particulares, delegando o Estado algumas de suas funções a iniciativa privada, sem, contudo, voltar ao Estado Liberal, passando o Estado somente exercer função reguladora sobre as atividades desenvolvidas.

Dessa forma, com o processo de desestatização atingindo o setor de serviços estatais, surgem as agências reguladoras. Entretanto, a venda das empresas estatais prestadoras de serviços trazia consigo o risco de o Estado perder totalmente o poder de influir na sua prestação e de controlar a estrutura empresarial.

Tanto quanto o sistema financeiro, sistemas como o elétrico ou de telecomunicações demandam autoridades fortes que os monitorem todo o tempo, porque são serviços fundamentais ao país, e seu colapso seria um verdadeiro desastre econômico.

Além disso, nesses campos se exerce um extraordinário poder econômico e o Estado não pode ficar indiferente à concentração empresarial excessiva ou fechar os olhos para as práticas

\footnotetext{
${ }^{3}$ Art. 170. A ordem econômica, fundada na valorização do trabalho humano e na livre iniciativa, tem por fim assegurar a todos existência digna, conforme os ditames da justiça social, observados os seguintes princípios: Parágrafo único. É assegurado a todos o livre exercício de qualquer atividade econômica, independentemente de autorização de órgãos públicos, salvo nos casos previstos em lei.

${ }^{4}$ Art. 174. Como agente normativo e regulador da atividade econômica, o Estado exercerá, na forma da lei, as funções de fiscalização, incentivo e planejamento, sendo este determinante para o setor público e indicativo para o setor privado.

${ }^{5}$ Art. 173. Ressalvados os casos previstos nesta Constituição, a exploração direta de atividade econômica pelo Estado só será permitida quando necessária aos imperativos da segurança nacional ou a relevante interesse coletivo, conforme definidos em lei.
} 
anticoncorrenciais (Sundfeld, 2006).

Como consequência das mudanças na economia do país, fez-se necessário a ocorrência de alterações substanciais no sistema legislativo, principalmente no que concerne a abertura ao capital estrangeiro na Constituição de $1988^{6}$, atenuação dos monopólios estatais ${ }^{7}$, e a instituição do Programa Nacional de Desestatização (PND) ${ }^{8}$. Assim, após modificações substanciais no aparato legislativo, optou-se por instituir as agências reguladoras como novo modelo de atuação do Estado regulador, ora interventivo.

Todavia, desde promulgada a Constituição Federal de 1988 evidenciava que o Estado deveria exercer as funções de fiscalização, incentivo e planejamento, atuando como agente normativo e regulador da atividade econômica, de forma determinante para o setor público e indicativo para o setor privado, como se observa nas linhas do art. 174 da Constituição Federal ${ }^{9}$. E, posteriormente, no ano de 1995, com a instituição das Emendas Constitucionais $\mathrm{n}^{\circ} .08$ e 09 foram previstas a criação e órgãos reguladores específicos para os setores de petróleo ${ }^{10}$ e telecomunicação ${ }^{11}$.

A Constituição Federal de 1988 não optou ou exigiu a criação das agências reguladoras, mas deixou essa opção para o legislador que optou pela utilização do modelo norte-americano, evidenciou-se, então, a partir da década de 90 um processo de "agencificação" que seria a outorga da função regulatória do Estado para as agências reguladoras (Di Pietro, 2005).

E ainda no Governo de Fernando Henrique Cardoso, houve a criação das agências reguladoras: Lei $\mathrm{n}^{0}$. 9.427/97 (ANEEL); Lei $\mathrm{n}^{0}$. 9.472/97 (ANATEL); Lei $\mathrm{n}^{0}$. 9.478/97 (ANP); Lei $n^{\circ}$. 9.782/99 (ANVISA); Lei $n^{\circ}$. 9.961/oo (ANS); Lei $n^{\circ} .9 .984 / 00$ (ANA); Lei $n^{\circ}$. 10.233/o1 (ANTAQ e ANTT); Medida Provisória nº . 2.228-1/o1 e Lei no ${ }^{\circ}$ 10.454/o2 (ANCINE);

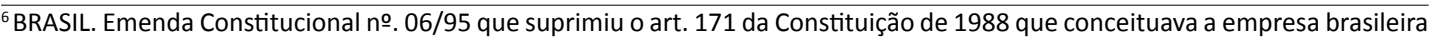
e admitia a outorga de e benefícios especiais e preferenciais, e ainda, alterou a redação do art. 176, §1으, permitindo a pesquisa e lavra de recursos minerais e aproveitamento das potências de energia elétrica concedidos e autorizados para empresas constituídas por leis nacionais, sem a exigência de capital nacional; Emenda Constitucional no 07/95 que alterou o art. 178 da Constituição de 1988; Emenda Constitucional no. 36/02 que alterou o art. 178 da Constituição de 1988 passando a admitir participação do capital estrangeiro, no limite de até $30 \%$, nas empresas jornalísticas e de radiofusão;

${ }^{7}$ BRASIL. Emenda Constitucional ํo. 05/95 alterou o art. 25, §2ㅇ da Constituição de 1988 permitindo que os Estados-membros concedam as empresas privadas a exploração de serviços público locais de gás canalizado; Emenda Constitucional no. 08/95, alterou o art. 21, XI da Constituição de 1988 permitindo a delegação de serviços de telecomunicações as empresas privadas, prevendo ainda a criação de um órgão regulador; Emenda Constitucional no. 09/95, alterou o art. 177, §1ㅇ da Constituição de 1988, autorizando contratação pela União de empresas estatais e privadas para execução de diversas atividades ligadas a exploração de petróleo. ${ }^{8}$ Programa Nacional de Desestatização (PND) pela Lei no. 8.031/90, substituída mais tarde pela Lei no. 9.491/97.

${ }^{9}$ Art. 174. Como agente normativo e regulador da atividade econômica, o Estado exercerá, na forma da lei, as funções de fiscalização, incentivo e planejamento, sendo este determinante para o setor público e indicativo para o setor privado.

${ }^{10} \mathrm{Art}$. 21. Compete a União: (...) XI - explorar, diretamente ou mediante autorização, concessão ou permissão, os serviços de telecomunicações, nos termos da lei, que disporá sobre a organização dos serviços, a criação de um órgão regulador e outros aspectos institucionais;(Redação dada pela Emenda Constitucional no 8, de 15/08/95:)

${ }^{11}$ Art. 177. Constituem monopólio da União: (...) I - a pesquisa e a lavra das jazidas de petróleo e gás natural e outros hidrocarbonetos fluidos; II - a refinação do petróleo nacional ou estrangeiro; III - a importação e exportação dos produtos e derivados básicos resultantes das atividades previstas nos incisos anteriores; IV - o transporte marítimo do petróleo bruto de origem nacional ou de derivados básicos de petróleo produzidos no País, bem assim o transporte, por meio de conduto, de petróleo bruto, seus derivados e gás natural de qualquer origem;

§ 1ํ A União poderá contratar com empresas estatais ou privadas a realização das atividades previstas nos incisos I a IV deste artigo observadas as condições estabelecidas em lei.

$\S 2$ ㅇ A lei a que se refere o $\S 1$ 1 disporá sobre: (...) III - a estrutura e atribuições do órgão regulador do monopólio da União.
} 
como forma do Estado tentar suprir as necessidades sociais e econômicas, diante do seu atual sistema de intervenção falido.

\subsection{NATUREZA JURÍDICA E CARACTERÍSTICAS}

As agências reguladoras são pessoas jurídicas de direito público, classificadas como autarquias em regime especial. Tal classificação é de notória importância para o desenvolvimento das suas funções, isso porque, ao serem criadas na forma de autarquias, são dotadas de autonomia em face dos entes políticos, e assim, não há interferência do Estado no desempenho das atividades com interferência no domínio econômico e fiscalização de prestação dos serviços públicos por parte das agências.

Por possuírem natureza autárquica, as agências reguladoras estão sujeitas ao disposto no art. 37, XIX da Constituição Federal de 1988 ${ }^{12}$, ou seja, necessitam de lei específica que as instituam e a extingam. E ainda, por serem criadas na forma especial são dotadas de maior estabilidade e autonomia administrativa em razão do seu ente criador, o que as distingue das tradicionais autarquias.

Outra demonstração dessa especialidade é no que concerne à investidura de seus dirigentes, que são nomeados pelo Presidente da República, mas distinguindo-se das demais autarquias, essa nomeação vai depender de prévia aprovação do Senado Federal, conforme previsto nos art. 84, XIV ${ }^{13}$, e 52, III, $\mathrm{f}^{14}$ da Constituição Federal de 1988, combinados com o art. $5^{\circ}$, da Lei $\mathrm{n}^{0} .9 .986 / \mathrm{oO}^{15}$, recebendo, por isso, a terminologia de investidura especial.

Além disso, os dirigentes têm mandato por prazo certo, fixado no ato da nomeação e a duração não deve ultrapassar a da legislatura do Presidente. E ainda no que diz respeito ao mandato dos dirigentes, há ainda o que a doutrina nomeia de quarentena, que ocorre quando terminado o mandato, o ex-dirigente é impedido por quatro meses de exercer qualquer atividade ou prestação de serviço no setor regulado pela agência, conforme dispõe o art. $8^{\circ}$ da

\footnotetext{
${ }^{12}$ Art. 37. A administração pública direta e indireta de qualquer dos Poderes da União, dos Estados, do Distrito Federal e dos Municípios obedecerá aos princípios de legalidade, impessoalidade, moralidade, publicidade e eficiência e, também, ao seguinte: (...) XIX - somente por lei específica poderá ser criada autarquia e autorizada a instituição de empresa pública, de sociedade de economia mista e de fundação, cabendo à lei complementar, neste último caso, definir as áreas de sua atuação;(Redação dada pela Emenda Constitucional no 19, de 1998).

${ }^{13}$ Art. 84. Compete privativamente ao Presidente da República: (...) XIV - nomear, após aprovação pelo Senado Federal, os Ministros do Supremo Tribunal Federal e dos Tribunais Superiores, os Governadores de Territórios, o Procurador-Geral da República, o presidente e os diretores do banco central e outros servidores, quando determinado em lei;

${ }^{14}$ Art. 52. Compete privativamente ao Senado Federal: (...) III - aprovar previamente, por voto secreto, após arguição pública, a escolha de: (...) f) titulares de outros cargos que a lei determinar;

${ }^{15}$ BRASIL. Lei no. 9.986, de 18 de julho de 2000, que dispõe sobre a gestão de recursos humanos das Agências Reguladoras e dá outras providências. (...) Art. 5o. Art. 50 O Presidente ou o Diretor-Geral ou o Diretor-Presidente (CD I) e os demais membros do Conselho Diretor ou da Diretoria (CD II) serão brasileiros, de reputação ilibada, formação universitária e elevado conceito no campo de especialidade dos cargos para os quais serão nomeados, devendo ser escolhidos pelo Presidente da República e por ele nomeados, após aprovação pelo Senado Federal, nos termos da alínea f do inciso III do art. 52 da Constituição Federal. Parágrafo único. O Presidente ou o Diretor-Geral ou o Diretor-Presidente será nomeado pelo Presidente da República dentre os integrantes do Conselho Diretor ou da Diretoria, respectivamente, e investido na função pelo prazo fixado no ato de nomeação.
} 
lei supracitada. ${ }^{16}$

Ainda, os Conselheiros e os Diretores somente perderão o mandato em caso de renúncia, de condenação judicial transitada em julgado ou de processo administrativo disciplinar, salvo se a lei que instituir a agência reguladora crie outras condições. ${ }^{17} \mathrm{E}$ sobre a organização dos demais cargos e carreiras, tem-se a Lei $\mathrm{n}^{0} .10 .871 / 04^{18}$ que dispõe sobre a criação de carreiras e organização de cargos efetivos das autarquias especiais, denominadas agências reguladoras, definindo o regime estatutário para os agentes, e sobre outras regras.

Outro item de fundamental importância na garantia da autonomia das agências reguladoras é a independência financeira em relação ao erário público, o que ocorre mediante a arrecadação de uma taxa de regulação devida pela concessionária diretamente a agência do setor regulado, taxa com relação direta em razão do proveito financeiro obtido com a concessão, e dessa forma, a agência não depende de verbas orçamentárias para o seu custeio.

Essa taxa de regulação tem natureza contratual, com pagamento contratualmente estipulado, pois é do contrato de concessão de serviços firmado entre o poder concedente e a concessionária que se origina a cobrança, que é fixada como forma de contrapartida para contratação da concessão, assegurando a segurança jurídica dos investimentos (Carvalho, 2012).

Entre as principais características das agências reguladoras, pode-se citar o poder normativo concedidos a essas autarquias, que mediante esse poder de normar podem editar normas abstratas infra legais de cunho legislativo, como forma de regulamentar o setor a ser regulado, pode-se dizer que seria uma delegação legislativa.

Há certa controvérsia na doutrina acerca dessa nomenclatura, e os autores avessos a essa ideia, justificam que em função da natureza desse instituto ser imune ao controle político, e somente poderiam as agencias emitir normas acerca de matérias de suas competências a partir de uma teoria sobre os regulamentos autônomos brasileiros (Cuèllar, 2001).

Outros doutrinadores consideram autênticas as delegações de poder legislativo as agências, porquanto, pautadas no imperativo de exercício de uma discricionariedade técnica, que funda-se em motivos de cunhos científicos e tecnológicos que tornam essa alternativa tecnicamente a mais viável ou a única adequada (Souto, 2002), até porque a criação de agências reguladoras como forma de descentralização da Administração e com o escopo de obter um maior controle dos serviços prestados, exige que todo um aparato de conhecimentos técnicos do setor regulado.

Diante disso, válido é o entendimento que a atribuição de poder normativo às agências reguladoras não exclui o poder de legislar, entretanto, significa o alargamento do desempenho

\footnotetext{
${ }^{16}$ Art. 8 o da Lei no. 9.986/00, diz que o ex-dirigente fica impedido para o exercício de atividades ou de prestar qualquer serviço no setor regulado pela respectiva agência, por um período de quatro meses, contados da exoneração ou do término do seu mandato.

${ }^{17}$ Art. 9o da Lei no. 9.986/00, dispõe que os Conselheiros e os Diretores somente perderão o mandato em caso de renúncia, de condenação judicial transitada em julgado ou de processo administrativo disciplinar. Parágrafo único. A lei de criação da Agência poderá prever outras condições para a perda do mandato.

${ }^{18}$ BRASIL. Lei no. 10.871, de 20 de maio de 2004, dispõe sobre a criação de carreiras e organização de cargos efetivos das autarquias especiais denominadas Agências Reguladoras, e dá outras providências.
} 
da função normativa do Estado. Destarte, o poder normativo atribuído às agências reguladoras é o que lhe torna peculiar e a diferencia dos papéis clássicos do Executivo, de forma que, excluir sua incidência seria obstruir sua própria essência. Necessário, aqui, a ênfase de que seu exercício depende de limites conferidos pela sua lei criadora, o que aparta o argumento de que se estaria diante de regulamentos autônomos (Amaral, 2008).

Também é válido ressaltar que a função normativa da agência reguladora é tão-somente técnica e direcionada ao setor regulado, o que requer a edição de normas por agentes especializados. Vale ressaltar que a edição dessas normas deve observar a participação da sociedade e do setor regulado, evitando a criação de um sistema repleto de normas tecnocráticas, que desvalorizam os valores humanos ao se ater a máxima racionalização.

Tal juízo seria incompatível com o atual estágio do Direito Administrativo que acompanho a evolução do Estado e da sociedade, acrescendo-se de um caráter valorativo, tornando-se necessário a justificação de suas decisões publicamente, respeitando o princípio da publicidade de suas decisões, disposto no art. 37, caput $^{19}$, da Constituição Federal de 1988.

Além disso, as normas reguladoras editadas por essas autarquias devem obedecer ao processo argumentativo, garantindo a sua legitimidade e assegurando que os interesses da coletividade sejam assegurados, e ainda, se necessário a legitimidade formal, ausentes a representação democrática, observar-se-á o princípio da participação, garantindo legitimidade substancial.

Ulterior particularidade das agências reguladoras é a certa independência confira a esses entes administrativos, sendo dotados de função quase judicial, que nada mais é do que o poder de solucionar conflitos de interesses, decidindo-os administrativamente esses conflitos entre os delegatários, o poder concedente, a própria agência e os usuários dos serviços prestados.

No caso dos serviços públicos podemos citar a Lei no ${ }^{\circ} .8 .987 / 95^{20}$, e ainda, as leis específicas instituidoras dessas autarquias preveem a sua competência para a tomada de decisões, como é o caso da Lei $n^{0}$. 9.427/96 ${ }^{21}$, instituidora da Agência Nacional de Energia Elétrica - ANEEL, que no art. $3, \mathrm{~V}^{22}$, atribui competência a esta para dirimir, no âmbito administrativo, as divergências entre concessionárias, permissionárias, autorizadas, produtores independentes e autoprodutores, bem como entre esses agentes e seus consumidores, bem como, as leis instituidoras das demais agências reguladoras preveem tal competência para solucionarem conflitos.

Entretanto, essa independência deve ser compatível com o regime constitucional brasileiro, e de modo algum pode-se afastar o princípio básico determinante em nosso sistema político

\footnotetext{
${ }^{19}$ Art. 37. A administração pública direta e indireta de qualquer dos Poderes da União, dos Estados, do Distrito Federal e dos Municípios obedecerá aos princípios de legalidade, impessoalidade, moralidade, publicidade e eficiência e, também, ao seguinte. ${ }^{20}$ BRASIL. Lei no. 8.987, de 12 de fevereiro de 1995, que dispõe sobre o regime de concessão e permissão da prestação de serviços públicos previsto no art. 175 da Constituição Federal, e dá outras providências.

${ }^{21}$ BRASIL. Lei no. 9.427, de 26 de dezembro de 1996, que Institui a Agência Nacional de Energia Elétrica - ANEEL, disciplina o regime das concessões de serviços públicos de energia elétrica e dá outras providências.

${ }^{22}$ Art. 3o Além das atribuições previstas nos incisos II, III, V, VI, VII, X, XI e XII do art. 29 e no art. 30 da Lei no 8.987 , de 13 de fevereiro de 1995, de outras incumbências expressamente previstas em lei e observado o disposto no $\S 10$, compete à ANEEL: (...)V - dirimir, no âmbito administrativo, as divergências entre concessionárias, permissionárias, autorizadas, produtores independentes e autoprodutores, bem como entre esses agentes e seus consumidores;
} 
democrático, predito pelo art. $5^{\circ}, \mathrm{XXXV} .{ }^{23}$

Assim, em relação ao Poder Judiciário, a suposta independência não existe, tendo em visto o sistema de unidade de jurisdição, garantido pelo artigo supracitado da Constituição Federal de 1988.

Logo, o fato de ser a última instância administrativa, a decisão tomada por ela não deve ser submetida a controle através de recurso hierárquico impróprio, e por ser evidentemente técnica não pode sofrer intromissão política, e com obviedade, não obsta recurso ao Judiciário para revisão dessas decisões no que se aplica aos atos administrativos (Mendes, 2006).

Pode-se afirmar que as competências das quais as agências reguladoras são dotadas fortalecem o Estado, porque retiram do emaranhado das lutas políticas a regulação de importantes atividades sociais e econômicas, atenuando a concentração de poderes na Administração Pública e, por conseguinte, alcançam de forma mais satisfatória o objetivo da separação de poderes, que é garantir de forma mais eficaz a segurança jurídica, proteção da coletividade e dos particulares, mantendo a probabilidade da interferência do Legislador, seja para alterar o regime jurídico da agência reguladora, ou mesmo para extingui-la (Aragão, 2006).

\subsection{AS AGÊNCIAS REGULADORAS BRASILEIRAS}

No que se refere à estrutura das agências reguladoras brasileiras, observa-se que estas têm sido criadas por leis esparsas, com estrutura e atribuições próprias, e além de independência técnica, deve possuir autonomia financeira e administrativa, recebendo seus recursos diretamente das concessionárias (Cal, 2003).

A primeira agência reguladora a ser instituída foi a Agência Nacional de Energia Elétrica - ANEEL, constituída pela Lei $n^{0}$. 9.427, de 26 de dezembro de 1996, é composta por um Diretor Geral e quatro Diretores, logo, dispõe de regime colegiado, nomeados pelo Presidente da República, com mandados não coincidentes de quatro anos, e os membros da Diretoria dependerão de prévia aprovação do Senado Federal, conforme art. 52, inciso III, alínea “f”24, da Constituição Federal. E ainda, faz parte da sua estrutura uma Procuradoria e que a função jurídica, ou seja, de defender a agência em juízo, e as superintendências regionais (Cal, 2003).

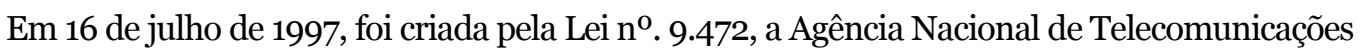
- ANATEL, que tem como órgão superior o Conselho Diretor - composto por cinco conselheiros, decidindo por maioria absoluta de votos, com mandado de cinco anos, nomeados pelo Presidente da República com aprovação pelo Senado - e, ainda, um Conselho Consultivo - órgão de participação institucionalizada da sociedade na agência -, uma Procuradoria - responsável por defender a

\footnotetext{
${ }^{23}$ Art. 5o Todos são iguais perante a lei, sem distinção de qualquer natureza, garantindo-se aos brasileiros e aos estrangeiros residentes no País a inviolabilidade do direito à vida, à liberdade, à igualdade, à segurança e à propriedade, nos termos seguintes: (...) XXXV - a lei não excluirá da apreciação do Poder Judiciário lesão ou ameaça a direito.

${ }^{24}$ Compete privativamente ao Senado Federal: (...) III - aprovar previamente, por voto secreto, após arguição pública, a escolha de: (...) f) titulares de outros cargos que a lei determinar.
} 
agência judicialmente -, uma Corregedoria - que avalia o desempenho funcional dos servidores da agência, sua eficiência e os processos disciplinares -, uma Biblioteca e uma Ouvidoria - que visa conhecer as reclamações dos usuários pela ausência ou ineficiência na prestação dos serviços -, bem como, unidades especializadas (Cal, 2003).

Ainda em 1997, foi instituída a Agência Nacional do Petróleo - ANP, pela Lei no . 9.478, de 06 de agosto de 1997, dirigida por regime Colegiado, por uma Diretoria - um Diretor Geral e quatro Diretores, com mandado de quatro anos, nomeados pelo Presidente da República nos termos do art. 52, inciso III, alínea "f" da Constituição Federal -, ainda integram a sua estrutura superintendências e um Procurador Geral. A deliberação de seus diretores contará com no mínimo três votos convergentes, e os atos decisórios deverão ser publicados no Diário Oficial da União - DOU, atendendo ao princípio administrativo da publicidade (Cal, 2003).

A Agência Nacional de Vigilância Sanitária - ANVISA, instituída pela Lei $n^{0}$. 9.782, de 26 de janeiro de 1999, é dirigida por uma Diretoria Colegiada, constituída por um Procurador, um Ouvidor e um Corregedor, e unidades especializadas. E, assim como a ANATEL, dispõe de um Conselho Consultivo - responsável por acompanhar o desenvolvimento das atividades realizadas -. Os Diretores são nomeados pelo Presidente da República nos termos do art. 52, inciso III, alínea "f" da Constituição Federal.

Em 28 de janeiro de 2000, foi criada a Agência Nacional de Saúde Suplementar - ANS, esta é dirigida por uma Diretoria Colegiada - composta por cinco Diretores e um DiretorGeral, com mandado de três anos, nomeados pelo Presidente da República, nos termos do art. 52, inciso III, alínea "f" da Constituição, e assim como a ANVISA, conta com um Corregedor, um Procurador e um Ouvidor, e ainda, a Câmara de Saúde Suplementar - esta possui caráter permanente e consultivo (Cal, 2003).

Já no caso da Agência Nacional de Águas - ANA, instituída pela Lei no . 9.984, de 17 de julho de 2000, esta também é dirigida por uma Diretoria Colegiada - constituída por cinco membros, com mandado de quatro anos, nomeados pelo Presidente da República, nos termos do art. 52, inciso III, alínea "f", da Constituição - e conta com uma Procuradoria - vinculada a Advocacia Geral da União, competente para representar a ANA judicialmente (CAL, 2003).

No caso das agências nacionais que regulam os transportes terrestres e aquaviários, a Agência Nacional de Transportes Terrestres - ANTT e Agência Nacional de Transportes Aquaviários - ANTAQ, ambas instituídas pela Lei $\mathrm{n}^{0}$. 10.233, de 05 de junho de 2001. Ambas são constituídas por Diretorias em regime colegiado, e assim como a ANVISA e a ANS, contam com um Procurador, um Corregedor e um Ouvidor, e as deliberações ocorrerão por maioria absoluta dos votos. Uma peculiaridade é que as relações trabalhistas serão regidas pela Consolidação de Leis do Trabalho - CLT, em regime de emprego público, podendo efetuar contratação temporária (Cal, 2003).

Ao analisar os parágrafos supra, identifica-se que existem várias diferenças, e cada agência possui peculiaridades próprias, isto porque, as agências são executoras de atividades diferentes, e tais particularidades variam de acordo com o setor de desempenho de cada agência. 
Pode-se apontar algumas falhas no ordenamento jurídico nas estruturas dessas agências instituídas por lei, entre elas, o fato de algumas agências exigirem aprovação do Senado Federal, nos termos do art. 52, inciso III, alínea "f", da Constituição Federal, após nomeação pelo Presidente da República, e outras não, como é o caso da ANA.

Além disso, como se observa, algumas agências não possuem ouvidoria, a exemplo da ANEEL, ANP e ANA, sendo que, a ouvidoria deveria ser vista como um dos órgãos mais importantes da estrutura de uma agência reguladora, e essa ausência constitui uma restrição às reclamações dos usuários do serviço, não sendo possível tomar ciência quanto á prestação do serviço pela concessionária.

Diante da diferenciação que existe na estrutura de cada agência reguladora, torna-se necessária uma uniformização, de forma que, sejam concedidas a cada ente regulador as mesmas regras, porque quando falamos em agências reguladoras, falando em uma única figura do ordenamento jurídico (Cal, 2003).

\subsection{O PODER NORMATIVO DAS AGÊNCIAS REGULADORAS}

O complexo grau de abstração e generalidade nas leis editadas pelo Poder Legislativo não suporta mais os novos padrões sociais, sendo imprescindível a edição de normas mais diretas para tratar de especificidades, planejar os setores e viabilizar a intervenção estatal para assegurar que a vontade da Constituição seja alcançada.

Justifica-se então a atribuição de poder normativo às agências reguladoras, que de modo algum exclui o poder de legislar, apenas incentiva o aprofundamento da atuação normativa do Estado (Sundfeld, 2006).

A natureza do poder de normar das agências reguladoras é regulamentar, sendo consequência da delegação de competência legislativa pela via da delegificação ou deslegalização.

Vislumbra-se uma solução para a sobrecarga do Legislativo, quando se viabiliza com a simplificação do processo legislativo, leia-se, pela entrega de parte da função normativa a outros órgãos ou instâncias estatais, em particular para o Executivo (Clève, 2000).

Não há como mensurar até onde o Executivo deixa de representar os interesses sociais como o Legislativo, mas, certo é que o conceito de lei, como comando normativo estatal derivado do Legislativo e composto das características de generalidade, abstração, impessoalidade e permanência, não se compatibilizam com a sociedade técnica (Clève, 2000).

Para compreender melhor essa atribuição de poder normativo às agências reguladoras é imperiosa analisar o contexto da complexidade e tecnicidade das relações sociais e econômicas, isto porque cabe ao Estado promover o bem comum de forma eficiente cumprindo os princípios democráticos e a concretização dos direitos fundamentais, assegurando a vontade da Constituição. 


\subsubsection{ACONSTITUCIONALIDADE DO PODER NORMATIVO DESTAS ENTIDADES}

Quando se fala em se constitucionalmente viável as agências reguladoras serem dotadas de poder normativo, não significa que elas podem produzir regulamentos autônomos, isto porque, todas as suas competências devem ter base legal, visto que, só a lei pode criá-las e conferir poderes para normar.

Sundfeld (2006) afirma:

"Quando reconheço ser constitucionalmente viável que elas desfrutem de um tal poder, de modo algum estou sugerindo que elas produzam 'regulamentos autônomos' ou coisa parecida, pois todas as suas competências devem ter base legal - mesmo porque só a lei pode criá-las, conferindo-lhes (ou não) poderes normativos (p.27)".

A constitucionalidade da lei atributiva depende de o legislador estabelece standards suficientes, o que não havendo, pode-se falar em delegação de função legislativa (Sundfeld, 2006).

Vale fazer uma breve diferenciação de poder normativo e poder legislativo, onde a competência normativa corresponde ao poder de produzir normas de conduta que gerarão comandos com o intuito de regular a conduta intersubjetiva, e a competência legislativa é o poder de normas jurídicas de cunho legislativo (Justen Filho, 2002).

Pode-se caracterizar a lei como ato jurídico estatal por meio do qual são produzidas normas jurídicas, o que pressupõe atividade própria do Estado, constituindo-se regras escritas de cunho vinculante, e a norma jurídica como comando acerca da conduta das pessoas, determinando que diante da verificação de certas conjecturas possa seguir uma conduta especifica ou genérica. Cabe ressaltar que no livro Ensaio sobre a Lei, Moncada (2002) referese ao objetivo do livro como "a caracterização da lei como norma jurídica" (p. 5).

Logo, fala-se em competência legislativa ao se referir a ato típico do Estado ao produzir a lei em si, e em competência normativa a produção de normas jurídicas que servem de norte para disciplinar a conduta humana, e que em última análise geram normas jurídicas (Justen Filho, 2002).

Assim, pode-se compreender competência normativa como produção de normas de caráter geral e abstrato, de cunho infralegal, podendo ser veiculada através de regulamentos, exercendo poder regulamentar, resoluções, portarias e outros, e que interfiram diretamente na esfera de direitos dos particulares (Mendes, 2006).

Portanto, as agências reguladoras são dotadas de competência normativa, e a natureza do poder de editar normas das agências reguladoras é regulamentar, sendo efeito da delegação de competência legislativa pela via da delegificação ou deslegalização.

A única manifestação permissiva expressa da delegação da atividade legislativa pela Constituição concerne às leis delegadas, sendo, em regra, vedada a delegação da ação normativa 
de competência do Congresso Nacional ao Executivo, conforme art. 25 do $\mathrm{ADCT}^{25}$.

Entretanto, no caso da ação normativa pelas agências reguladoras, não se aplica a vedação, isto porque veda-se a Administração Pública, em regra, que exerça competência que é atribuída aos órgãos legislativos, o que não se sobrepõe ao poder normativo inerente ao exercício da função administrativa, sem o qual não poderia aplicar às leis e especificar matérias como por elas exigido (Andrade, 2008).

\subsubsection{A DESCENTRALIZAÇÃO NORMATIVA NO ESTADO BRASILEIRO}

A recusa do poder normativo ao Executivo não evita uma crise democrática, se o fato de outorgar esse poder ao Executivo pode originar arbítrio, ameaçando a democracia, recusar poderá destruí-la. Quando se recusa a atribuir poder normativo a quem possui condições de exercitá-lo, com maior eficiência, pode-se tonar o governo impotente e ocasionar um verdadeiro desastre à democracia (Ferreira Filho, 2007).

Diante do pensamento harmônico dos princípios democráticos que se fundam na ideia do bem comum, se faz necessária releitura dos princípios da legalidade e da tripartição de poderes para a consecução do Estado constitucional democrático de direito, abandonando os formalismos arraigados no princípio da legalidade e da tripartição de poderes.

As competências destinadas às agências reguladoras independentes fortalecem o Estado democrático de direito, de forma que, atenuando a concentração de poderes na Administração Pública, obtêm com melhor proveito a consecução do objetivo da separação de poderes, garantindo de forma mais eficaz a segurança jurídica e a proteção da sociedade e dos particulares, mantendo-se a possibilidade de interferência do Legislador para alterar o regime jurídico da agência reguladora, ou mesmo para extingui-la (Aragão, 2006).

Óbvio é a necessidade da atividade legislativa, porém, ao assumir a concepção de Estado democrático de direito, tal função legislativa deve ser repartida com o Executivo, entretanto, o Legislativo não deve deixar de reforçar o seu poder de controle sobre os atos, inclusive normativos, efetuados pelo Executivo (Aragão, 2000).

No Brasil, a Reforma Administrativa de 1995, trouxe consigo a necessidade de flexibilidade da gestão pública no exercício da função administrativa, e o então presidente Fernando Henrique Cardoso, criou uma estrutura organizacional objetivando efetivar uma ampla mudança administrativa, sob a orientação de um modelo gerencial voltado para eficiência (Lehfeld, 2008).

Nesse contexto, insere-se a mudança da Secretaria de Administração Federal da Presidência da República - SAF para um novo ministério chamado Ministério da Administração

\footnotetext{
${ }_{25}$ Art. 25. Ficam revogados, a partir de cento e oitenta dias da promulgação da Constituição, sujeito este prazo a prorrogação por lei, todos os dispositivos legais que atribuam ou deleguem a órgão do Poder Executivo competência assinalada pela Constituição ao Congresso Nacional, especialmente no que tange a: I - ação normativa.
} 
Federal e Reforma do Estado - MARE, e ainda, foram instalados a Câmara da Reforma do Estado e o Conselho de Reforma do Estado, buscando a deliberação sobre planos e projetos visando implementar a reforma administrativa (Lehfeld, 2008).

Logo foram estabelecidos objetivos no Plano Diretor da Reforma do Aparelho do Estado, e entre esses objetivos, uma linha de ação institucional-legal com a remoção de barreiras legais e normativas para a instituição da descentralização administrativa, com a criação de agências autônomas, e diante da preocupação em efetivar tais mudanças surge a proposta de Emenda à Constituição e de uma legislação infraconstitucional, como forma de incorporar à Administração Pública novas instituições, e uma reorganização da prestação dos serviços públicos (Lehfeld, 2008).

Com o advento da Emenda Constitucional - $\mathrm{EC} \mathrm{n}^{\circ} 19 / 98$, institucionalizou-se o princípio da eficiência e formalizou a importância da autonomia como conditio sine qua non do processo de descentralização administrativa, buscando-se, assim, a qualidade da atividade estatal.

O princípio da eficiência, presente no art. 37, da Constituição Federal, representa o mais importante objetivo da Reforma Administrativa, levando a remodelação das funções da Administrativa Pública, não competindo apenas executar as leis, mas, sobretudo, satisfazer os interesses coletivos (Lehfeld, 2008).

A instituição das agências reguladoras dotadas de poder normativo no cenário políticoadministrativo brasileiro fortaleceu o Executivo, que passou a obter maior destaque na mediação política com o setor econômico e, por conseguinte, com o setor privado.

Entretanto, se faz necessário a manifestação do princípio da accountability - controle parlamentar - para legitimar o modelo regulatório implantado e, assim, para garantir a eficácia dos marcos de regulação e, consequentemente, a eficiência do processo de desestatização, é imperioso a prestação de contas e justificativa dos atos e decisões tomadas pelas agências ao Legislativo (Lehfeld, 2008).

Evidencia-se a necessidade de adaptação dos princípios da legalidade e da tripartição dos poderes à contemporaneidade dos clamores, não só políticos, como sociais e econômicos. Sucede que, a clássica produção normativa pelo Legislativo revela-se tecnicamente despreparada para regulamentar certas matérias, e ainda, não acompanha a dinamicidade das relações sociais atuais.

\subsubsection{A FINALIDADE DO PODER NORMATIVO DAS AGÊNCIAS REGULADORAS}

A função reguladora inicia-se com o processo de deslegalização, por meio do qual o Congresso transfere a disciplina de certas tarefas ao ente regulador. Consiste em um híbrido das três funções clássicas do Poder estatal, cumprindo a ela o exercício não apenas da função administrativa, incumbida da gestão da res publica, mas, também e fundamentalmente, da função normativa e da função judicativa (Amaral, 2008).

A função normativa não se confunde com a tradicional função regulamentadora da Administração Pública, positivada no art. 84, inciso IV, da Constituição, onde a esta compete 
a fiel execução da lei e dela deriva a expedição dos atos normativos, isto porque, não podem criar obrigações nem impor comportamentos aos administrados não previstos por lei e, assim, não inovam no ordenamento jurídico (Amaral, 2008).

Pode-se definir deslegalização como a forma do legislador retirar certas matérias do domínio da lei e atribuí-las às agências reguladoras para, assim, disciplina-las (Figueiredo, apud Amaral, 2008).

Alguns doutrinadores rejeitam a ideia de que o poder normativo dos entes reguladores se justifica pela deslegalização, em razão da natureza precária, excepcional e imune a controle político, mas, reconhecem que estes possuem prerrogativas para emitir normas sobre matérias de suas competências, a partir de uma teoria sobre os regulamentos autônomos brasileiros (Cuèllar, 2001).

Há, ainda, doutrinadores que reconhecem a existência da função reguladora tãosomente das agências que têm previsão constitucional, à exemplo da ANATEL e a ANP, conforme disposto nos arts. 21, inciso XI e 177, $\S 2^{\circ}$, inciso III, ambos da Constituição. Sob esta perspectiva, defendem que a delegação realizada pela instituidora da agência reveste-se de inconstitucionalidade, não podendo regular matéria não anteriormente disciplinada em lei, tendo em vista a ausência de fundamento constitucional para os regulamentos autônomos no ordenamento jurídico (Di Pietro, 2007).

Mas, logo afasta-se o argumento de inconstitucionalidade na deslegalização, pois não há evidentemente uma cessão de poderes legislativos às agências reguladoras, mas apenas a adoção, pelo próprio legislador, de uma política legislativa pela qual confere a uma outra sede normativa a regulação de certa matéria.

Destarte, desde que a função normativa da agência reguladora seja entendida como restringidas aos limites estabelecidos previamente em lei, para uma atuação meramente técnica e livre de inconstitucionalidade e, assim, não ocorrerá usurpação de função legislativa, logo, a atribuição de poder normativo às agências reguladoras não exclui o poder de legislar, constituindo-se o aprofundamento da atuação normativa do Estado (Sundfeld, 2006).

Ressalta-se que o poder normativo conferido as agências reguladoras é meramente técnico e direcionado ao setor regulado por estas, portanto, requer que as normas sejam editadas por agentes especializados. Mas, a norma deve obedecer um processo argumentativo para garantir que os interesses relevantes da sociedade sejam assegurados, revestindo-se da necessária legitimidade, pautando-se no princípio da participação (Amaral, 2008).

\subsubsection{O EXERCÍCIO DA FUNÇÃO NORMATIVA COM FUNDAMENTO NOS STANDARDS}

Faz-se imprescindível a percepção que a lei instituidora das agências reguladoras terá que estabelecer limites para ação normativa destas por meio de Standards, assim, os regulamentos editados por essas autarquias especiais devem ser entendidos como delegados, e distinguem-se, 
portanto, do regulamento autônomo e de execução.

Entretanto, a lei deslegalizadora determinará o teor material da futura normatização perpetrada pela Administração Pública, se limitando a estabelecer Standards e princípios a serem respeitados na atividade administrativo-normativo (Oliveira, 2010).

Explica-se que por Standards entendem-se as normas gerais e abstratas, em que a competência para operacionalização prática competirá às agências reguladoras, por determinação das leis que as instituírem, cabendo ao Legislativo estabelecer no momento da criação do ente regulador, sob orientações do Executivo, tais normas que serão operacionalizadas pela autarquia em regime especial (Lehfeld, 2008).

Assim, as agências reguladoras possuem competências normativas embasadas nos Standards, logo, seus poderes normativos são determinados legalmente pelo Legislativo quando da criação dessas autarquias.

Aragão (2006) afirma:

"Podemos ver, com efeito, que apesar da maior ou menor magnitude de poder normativo legalmente outorgado nas suas esferas de atuação, todas as agências reguladoras - umas mais e outras menos - possuem competências normativas calcadas em Standards, ou seja, em palavras dotadas de baixa densidadenormativa, às vezes meramente habilitadoras, devendo exercer estas competências na busca da realização das finalidades públicas - também genéricas - fixadas nas suas respectivas leis (p. 408)".

As leis que estabelecem essas autarquias em regime especial associam-se, deste modo, a categoria das standartizadas, concernentes às matérias de maior complexidade técnica e dos setores suscetíveis a constantes mutações econômicas e tecnológicas (Aragão, 2006).

Além disso, ressalta-se que a constitucionalidade da lei atributiva do poder normativo depende de o legislador estabelecer Standards suficientes, caso contrário, existiria legítima delegação de função legislativa (Sundfeld, 2006).

Todo esse repasse de poder normativo para as agências reguladoras faz sentido no contexto da complexidade e tecnicidade das relações sociais e econômicas, já que o Estado se incumbiu de promover o bem comum de forma eficiente, atendendo aos princípios democráticos e aos preceitos da justiça social.

Por consequência, o poder normativo das agências reguladoras tem de encontrar harmonização com a vontade constitucional. A utilização do instituto das agências caminha para a concretização do bem comum, operando para assegurar direitos fundamentais e protegendo a sociedade por meio de normas, com a finalidade de atender o equilíbrio econômico, a justiça social e a dignidade humana, compatível são elas, pois, com a Constituição e com o Estado Democrático. Até porque, a sua forma de atuação produtiva de normas está limitada aos Standards contidos na Lei que as criou. 


\section{CONSIDERAÇÕES FINAIS}

As Agência Reguladoras, ao que se percebe, surgem no Brasil como um meio de apoio necessário para que o Estado possa atender as necessidades de uma sociedade cada vez mais técnica e complexa, no contexto da regulação de determinados setores, em virtude do processo desestatização que se desencadeou a partir de 1990.

Com as privatizações, o Estado passou à iniciativa privada a prestação de serviços antes prestados apenas por ele. Isso trazia consigo o risco de o Estado perder totalmente o poder de influir na prestação de tais serviços e de controlar a estrutura empresarial, razão pela qual as agências reguladoras seriam necessárias para regulação de setores onde houve a desestatização.

Essas autarquias apresentam características que as diferenciam das demais, dentre as quais, já observadas acima, está o objeto do presente trabalho, qual seja, o poder normativo, pelo que se avalia a sua constitucionalidade.

É certo que o complexo grau de abstração e generalidade nas leis editadas pelo Poder Legislativo não mais se mostra condizente nem suficiente para atender todas as demandas sociais, sendo imprescindível a edição de normas mais diretas e técnicas para tratar de especificidades, planejar os setores e viabilizar a intervenção estatal para assegurar que a vontade da Constituição seja alcançada.

Daí a necessidade de as agências reguladoras serem dotadas de poder normativo, sendo regulamentar a natureza do poder de editar normas dessas autarquias, o que se obtém pela via da delegificação ou deslegalização, o que não encontra impedimento constitucional, conforme anotado acima, pois se trata de poder normativo inerente ao exercício da função administrativa.

Constata-se que essas competências das quais as agências reguladoras são dotadas fortalecem o Estado e a própria Constituição, atenuando a concentração de poderes na Administração Pública e retirando-se das lutas políticas, e assim, concretizam de forma mais satisfatória o objetivo da separação de poderes, que é assegurar de forma mais eficaz a segurança jurídica, proteção da coletividade e dos particulares, e ainda, mantendo a possibilidade da intromissão do Legislador, para modificar o regime jurídico da agência reguladora ou mesmo para extingui-la.

É, pois, imprescindível, repensar a forma de aplicação dos princípios da tripartição de poderes e da legalidade, devendo estes passar por uma nova leitura, de forma a reconhecer que o poder normativo das agências reguladoras não os contrariam. Isso porque, essas autarquias atuam para suprir a falta de conhecimento técnico dos Parlamentares, a inércia do Legislativo para a normatização de certas matérias e para evitar a superposição de interesses pessoais de integrantes da Casa Legislativa sobre os interesses da sociedade.

Além disso, as agências reguladoras atuam no sentido de proteger e fazer valer princípios e direitos fundamentais assegurados na Constituição, atuando amparadas pelo manto desta, em busca de efetivação e realização de uma democracia material.

Logo, o poder normativo das agências reguladoras se mostra indispensável para a atividade reguladora do Estado, editando normas fundamentais para a proteção e concretização da 
democracia e do equilíbrio econômico, o que reflete, inevitavelmente, a vontade constitucional e caminha no sentido do bem-estar social.

Dessa forma, pretende-se firmar o entendimento de que o poder normativo das agências reguladoras é constitucional e condizente com o Estado constitucional democrático de direito.

\section{REFERÊNCIAS BIBLIOGRÁFICAS}

Amaral, A. d. (2008). Princípios Estruturantes das Agências Reguladoras e os Mecanismos de Controle. Rio de Janeiro: Lúmen Júris.

Andrade, L. Q. (Ago/Set/Out de 2008). Poder normativo das agências reguladoras (legitimação, extensão e controle). (I. d. Público, Ed.) Revista eletrônica de Direito Administrativo Econômico(15). Fonte: www.direitodoestado.com.br

Aragão, A. S. (outubro-dezembro de 2002). Legalidade e regulamentos Administrativos no direito contemporâneo. Uma análise doutrinária e jurisprudencial. Revista de Direito Constitucional e Internacional (41).

Cal, A. B. (2003). As agências reguladoras no direito brasileiro. Rio de Janeiro: Renovar.

Clève, C. M. (2000). Atividade legislativa do poder executivo ( $2^{\circ}$ ed.). São Paulo: Revista dos Tribunais.

Cuéllar, L. (2001). As agências reguladoras e seu poder normativo. São Paulo: Dialética.

Di Pietro, M. S. (2005). Parcerias na administração pública: concessão, permissão, franquia, terceirização, parceria público privada e outras formas ( $5^{\circ}$ ed.). São Paulo: Atlas.

Di Pietro, M. S. (2007). Direito Administrativo (20º ed.). São Paulo: Atlas.

Dos Santos Carvalho Filho, J. (dezembro/janeiro/fevereiro de 2001). Estado Mínimo x Estado Máximo: O Dilema. (I. B. Público, Ed.) Revista Eletrônica sobra a Reforma do Estado (RERE). Fonte: www.direitodoestado.com.br/rere.asp

Ferreira Filho, M. G. (2007). Do Processo Legislativo (6º ed.). São Paulo: Saraiva. 
Justen Filho, M. (2002). O direito das agências reguladoras independentes. São Paulo: Dialética.

Lehfeld, L. d. (2002). Controles das agências reguladoras. São Paulo: Atlas.

Mendes, C. H. (2006). Reforma do Estado e Agências Reguladoras: Estabelecendo os Parâmetros de Discussão. Em C. A. SUNDFELD, Direito administrativo econômico. São Paulo: Malheiros.

Oliveira, R. C. (2010). Constitucionalização do direito administrativo. Rio de Janeiro: Lumen Juris.

Souto, M. J. (2002). Direito Administrativo regulatório. Rio de Janeiro: Lúmen Júris.

Sundfeld, C. A. (2006). Serviços Públicos e Regulação Estatal: Introdução às Agências Reguladoras. Em C. A. SUNDFELD, Direito administrativo econômico. São Paulo: Malheiros.

\section{CURRICULUM VITAE}

\section{Cristina Alves da Silva Braga}

Universidade Anhanguera-Uniderp, Campo Grande - MS, BRASIL.

Graduou-se em Direito pela Faculdade de Ciências Cultura e Extensão do Rio Grande do Norte (2012). Especialista em Direito Administrativo da Universidade Anhanguera Uniderp (2014). Atualmente é advogada, atuando principalmente nas áreas de Direito Administrativo e Previdenciário. Assessora Jurídica no Sindicato dos Trabalhadores em Educação Pública do Rio Grande do Norte - SINTE-RN.

criistina.silva@gmail.com

\section{Rocco Antonio Rangel Rosso Nelson}

Graduou-se em direito pela Universidade Potiguar (2004). Especializou-se em Ministério Público, Direito e Cidadania pela Fundação Escola Superior do Ministério Público do Rio Grande do Norte (2007), bem como na área de Direito Penal e Criminologia pela Universidade Potiguar (2007). Mestre em Direito Constitucional pela Universidade Federal do Rio Grande do Norte (2009). Foi professor da Faculdade de Ciências Cultura e Extensão do Rio Grande do Norte - FACEX, por um período de 5 anos, tendo lecionados as cátedras de Direito Penal - I, Direito Penal II, Direito Penal III, Direito Penal IV, Direito Processual Penal - I e Direito Processual Penal - II, Direito 
Processual Constitucional, Direito Tributário, Direito Empresarial, Direito Administrativo, Direito da Seguridade Social. Lecionou nas pós-graduações "lato sensu" em MBA em Gestão Pública, MBA em Gestão Financeira, MBA em Auditoria e Perícia Contábil, em Elaboração e Gerenciamento de Projetos e em Assistência Sócio-jurídica e Segurança Pública. Já ministrou aulas na faculdade Estácio de Sá e na Universidade Federal do Rio Grande do Norte - UFRN. Atualmente, professor de Direito, no Instituto Federal do Rio Grande do Norte - IFRN, articulista e poeta.

rocconelson@hotmail.com 